\title{
Coral Reef Coverage Percentage on Binor Paiton-Probolinggo Seashore
}

\author{
Dwi Budi Wiyanto \\ ${ }^{a}$ Marine Science Departement, Faculty of Marine Science and Fisheries, Udayana University, Bukit Jimbaran, Bali 80361, Indonesia \\ * Penulis koresponden. Tel.: +62-361-702-802 \\ Alamate-mail: wiyanto_marine@yahoo.com
}

Diterima (received) 2 Desember 2015; disetujui (accepted) 18 Februari 2016; tersedia secara online (available online) 21 Februari 2016

\begin{abstract}
Abstrak
Berkaitan dengan pengelolaan ekosistem terumbu karang, ketersediaan data yang akurat sangat dibutuhkan untuk mendukung arah kebijakan yang akan dilaksanakan, sehingga diperlukan penelitian tentang prosentase tutupan terumbu karang ini secara kontinyu. Tujuan penelitian ini adalah mengumpulkan data biologi mengenai terumbu karang dan mengetahui persentase penutupan terumbu karang dalam rangka penyusunan basis data kondisi terumbu karang di perairan Pantai Binor, Paiton, Kabupaten Probolinggo. Metode yang digunakan dalam kegiatan penelitian ini adalah metode Line Intercept Transect (LIT). Metode LIT merupakan metode yang digunakan untuk menentukan komunitas bentik sesil di terumbu karang berdasarkan bentuk pertumbuhan dalam satuan persen, dan mencatat jumlah biota bentik yang ada sepanjang garis transek. Persentase tutupan karang hidup pada kedalaman 3 meter di perairan Binor Paiton ini dikategorikan dalam kondisi baik yaitu sebesar 57,65 \%. Sedangkan persentase karang mati hanya 1,45 \%, kemudian biota lain $23,2 \%$, abiotik $17,7 \%$. Kondisi terumbu karang yang baik dikarenakan adanya penanaman terumbu karang (transplantasi karang) diperairan tersebut, sehingga terumbu karang didominasi oleh Acropora Branching. Sedangkan Indeks Mortalitas (IM) Terumbu Karang mencapai 24,5\%. Hasil pengamatan dan pengukuran terumbu karang diperairan tersebut didominasi oleh Hard Coral yaitu Acropora Branching (ACB) dengan persentase tutupan terumbu karang sebesar $39 \%$, Coral Massif (CM) dengan persentase tutupan terumbu karang sebesar $2,85 \%$, Coral Foliose (CF) dengan persentase tutupan terumbu karang sebesar $1,6 \%$, dan Coral Mushroom (CMR) dengan persentase tutupan terumbu karang sebesar 8,5\%. Pengamatan pada kedalaman 10 meter, penutupan terumbu karang mencapai 63,33\%. $75 \%$ karang hidup yang ditemukan di kedalaman 10 meter di dominasi oleh karang Acropora bercabang, dan 25,21\% lainnya diisi oleh karang Acropora meja (tabulate) dan karang non-Acropora dengan bentuk hidup bercabang, massif, submassif, lembaran, dan jamur, sedangkan Indek Mortalitas (IM) karang mencapai 28,5\%. Tingginya persentase penutupan karang di Paiton disebabkan oleh keberhasilan kegiatan transplantasi karang serta minimnya kegiatan manusia di lokasi ini. Dominansi karang Acropora bercabang berukuran besar yang diperkirakan hanya dari sedikit jenis, menunjukkan bahwa karang hasil transplantasi telah tumbuh besar dan membentuk struktur 3 dimensi karang yang kompleks yang sangat cocok untuk biota ikan dan bentik hidup.
\end{abstract}

Keywords: prosentase tutupan; terumbu karang; perairan Pantai Binor Paiton-Probolinggo

\begin{abstract}
The coral reef damage in Probolinggo region was expected to be caused by several factors. The first one comes from its society that exploits fishery by using cyanide toxin and bomb. The second one goes to the extraction of coral reef, which is used as decoration or construction materials. The other factor is likely caused by the existence of large industry on the seashore, such as Electric Steam Power Plant (PLTU) Paiton and others alike. Related to the development of coral reef ecosystem, availability of an accurate data is crucially needed to support the manner of future policy, so the research of coral reef coverage percentage needs to be conducted continuously. The aim of this research is to collect biological data of coral reef and to identify coral reef coverage percentage in the effort of constructing coral reef condition basic data on Binor, Paiton, and Probolinggo regency seashore. The method used in this research is Line Intercept Transect (LIT) method. LIT method is a method that used to decide benthic community on coral reef based on percentage growth, and to take note of benthic quantity along transect line. Percentage of living coral coverage in 3 meters depth on this Binor Paiton seashore that may be categorized in a good condition is $57,65 \%$. While the rest are dead coral that is only $1,45 \%$, other life form in $23,2 \%$, and non-life form in $17,7 \%$. A good condition of coral reef is caused by coral reef transplantation on the seashore, so this coral reef is dominated by Acropora Branching. On the other hand, Mortality Index (IM) of coral reef resulted in 24,5\%. The result from observation and calculation of coral reef is dominated by Hard Coral in Acropora Branching (ACB) with coral reef coverage percentage of 39\%, Coral Massive (CM) with coral reef coverage percentage of 2,85\%, Coral Foliose (CF) with coral reef coverage percentage of 1,6\%, and Coral Mushroom (CRM) with coral reef coverage percentage of 8,5\%. Observation in 10 meters depth resulted in coral reef coverage percentage of $63,33 \% .75 \%$ of living coral found on this 10 meters depth are dominated by Acropora branching coral, while the rest $25,21 \%$ are filled by Acropora tabulate coral and non-Acropora coral in the life form of branching, massive, sub-massive, foliose, and mushroom, where coral Mortality Index (IM) reached 28,5\%. The high number of coral reef coverage percentage on Paiton is caused by successful coral transplantation and low activity of society in this location. The domination of large size Acropora branching coral were estimated comes from a few types, showing that coral resulted from transplantation has grown large and form a complex 3 dimension structure that is suitable for the life form of fish and living benthic.
\end{abstract}

Keywords: Coverage Percentage, Coral Reef, Binor Paiton-Probolinggo Seashore 


\section{Introduction}

Coral reef is a dynamic and integrated ecosystem with mineral construction material that transferred by plants and animals. These kind of elements that caused coral reef to become an ecosystem with high variety and complexity. The existence of surrounding area may also caused coral reef to turn into a fragile and broken state rapidly, since coral is well grown near warm ocean water surface and close to the land. As changes occur in maritime condition, air or land that interacted to the ocean may affect the life of coral ecosystem (Buddemeier and Kinzie, 1976). Indonesia has around $50.000 \mathrm{~km}^{2}$ of coral reef ecosystem that spread out through the National maritime. It holds approximately $80.802 \mathrm{ton} / \mathrm{km}^{2} /$ year of healthy fishery resources potential.

In 2008, coral reef condition in western part of Indonesia is very good $(5,47 \%)$; good $(27,56 \%)$; fair $(33,94 \%)$; inadequate $(33,03 \%)$. Coral reef condition in central part of Indonesia is very good $(5,11 \%)$; good $(30,29 \%)$; fair $(44,89 \%)$; inadequate $(19,71 \%)$. Coral reef condition in eastern part of Indonesia is very good $(5,88 \%)$; good $(17,28 \%)$; fair $(34,19 \%)$; inadequate (42,65\%; Sjafrie, 2009).

Damages of coral reef are mostly caused by large scale of exploits. The main threat of coral reef is overwhelming catch of fish, destructive ways of catching fish, sedimentation and pollution from land. Human activities nowadays are predicted to cause $88 \%$ harm to South East Asia coral reef, threatening vital biological and economical value to the society. Around $50 \%$ of the threatened coral reefs are in the high or very high level of threat. Only $12 \%$ of those are in the fair level of threat (Burke et., al. 2002).

In this work, attempts have been made to identify coral reef coverage percentage in the effort of constructing coral reef condition basic data on Binor, Paiton, and Probolinggo regency seashore. In addition, differences investigated also done to recognize coral reef condition on Binor, Paiton, and Probolinggo regency seashore.

\section{Data and Analysis}

\subsection{Research Time and Place}

This research conducted on July 2011. Generally, the research is located on Binor, Paiton, and Probolinggo regency seashore. Map of the research site displayed by Figure 1.

\subsection{Research Tools and Material}

The tools used in this research are scuba diving equipment, High Pressure Compressor, Deep Scan, Underwater Camera photo, Roll Meter (for underwater transect), Underwater stationery, Coral identifier book and GPS to pinpoint the location. Material used in this research is the coral reef that found on Binor PaitonProbolinggo Seashore.

\subsection{Research Method}

The method used in this research is Line Intercept Transect (LIT) method. LIT method is a method that frequently used to decide benthic community on coral reef based on percentage growth, and to take note of benthic quantity along transect line. Community classified by using category of life form that gives a descriptive display from the morphology of coral community. LIT also used to observe coral reef condition in details by using permanent transect line. (English et al., 1994). Klasififikasi lifeform ada di Tabel 1.

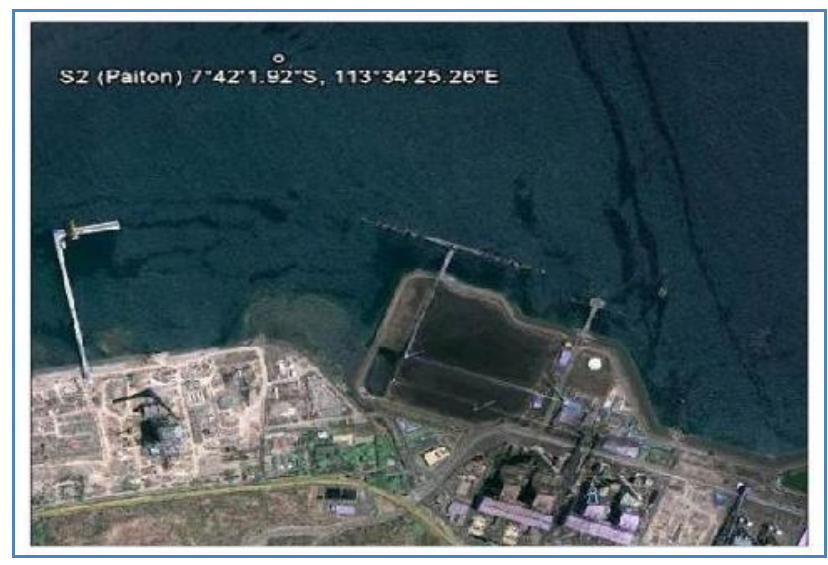

Figure 1. Research Site.

LIT operational procedures according to (English et al., 1994) are as follow:

1. Observer represented by two people; one person assigned to make the transect, while the other one assigned to take note of any coral life form category found.

2. Transect made in two kinds of depths ( 3 and 10 meters). Transect length is 100 meters. Transect line made by spreading roll meter in its centimeters $(\mathrm{cm})$ scale.

3. Observer must be familiar and fully comprehend the classification of coral growth form, whether it is a living coral or any other biota.

4. Observer swim from point zero up to the point of 100 meters by following transect line made and take note of all coral life form in the area passed by transect line. Every life form should be noted of its width (until centimeters scale). Life form category may refer to AIMS (English et al., 1994) or COREMAP.

5. If possible, observer may also indentify observed coral type in minimum up to its taksa genus.

Coverage percentage of each coral life form category according to (English et al., 1994) may be found by using the following formula;

Coverage Persentage $=\frac{\text { total length of each category }}{\text { total length of } \text { cransect }} \times 100 \%$

Coverage percentage for all categories of living coral life form according to (English et al., 1994) may be found by using the following formula; 
Coverage Persentage $=\frac{\text { total length of all categories living coral reefotal length of each category }}{\text { total length of transect }} \times 100 \%$

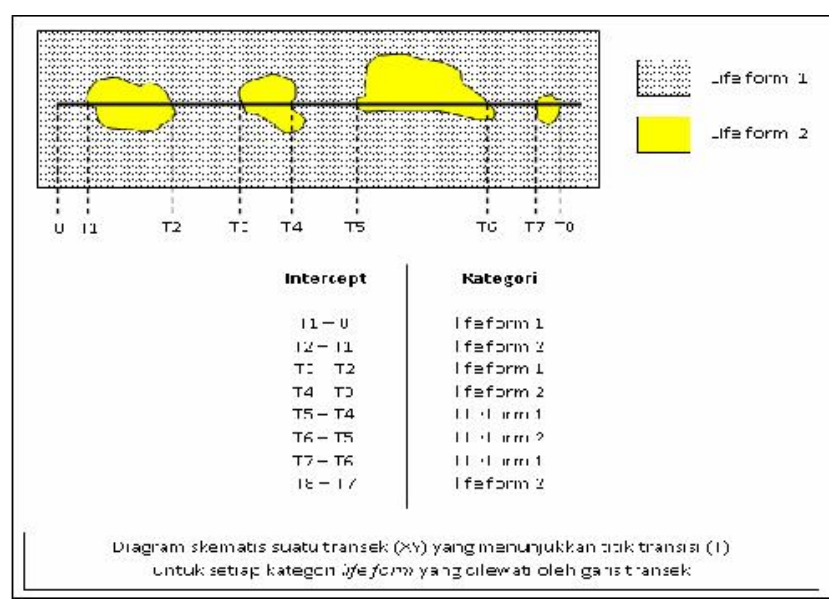

Figure 2. Data record model of coral life form

Table 1.

Life form list and each code

\begin{tabular}{|c|c|c|c|}
\hline Category & Code & Category & Code \\
\hline $\begin{array}{l}\text { Hard Corals } \\
\text { Acropora group } \\
\text { - } \quad \text { Branching } \\
\text { - Encrusting } \\
\text { - } \quad \text { Submassive } \\
\quad \text { (digitate) } \\
\text { - Tabulate }\end{array}$ & $\begin{array}{l}\text { ACB } \\
\text { ACE } \\
\text { ACS } \\
\text { ACT }\end{array}$ & $\begin{array}{cl}\text { Algae } & \\
\text { - } & \text { Macro } \\
\text { - Turf } \\
\text { - Coraline } \\
\text { - Halimeda } \\
\text { Algae } \\
\text { Assemblage }\end{array}$ & $\begin{array}{l}\text { MA } \\
\text { TA } \\
\text { CA } \\
\text { HA } \\
\text { AA }\end{array}$ \\
\hline $\begin{array}{ll}\text { Non-Acropora group } \\
\text { - } & \text { Branching } \\
\text { - } & \text { Encrusting } \\
\text { - } & \text { Foliose } \\
\text { - } & \text { Massive } \\
\text { - } & \text { Submassive } \\
& \text { (digitate) } \\
\text { - } & \text { Mushroom } \\
\text { - } & \text { Millepora (fire } \\
& \text { coral) } \\
\text { - Heliopora (Blue } \\
\\
\text { coral) }\end{array}$ & $\begin{array}{c}\mathrm{CB} \\
\mathrm{CE} \\
\mathrm{CF} \\
\mathrm{CM} \\
\mathrm{CS} \\
\mathrm{CMR} \\
\mathrm{CME} \\
\mathrm{CHL}\end{array}$ & $\begin{array}{c}\text { Other Fauna } \\
\text { - Soft Corals } \\
\text { - Sponge } \\
\text { - Zoanthid } \\
\text { - } \text { Other }\end{array}$ & $\begin{array}{l}\text { SC } \\
\text { SP } \\
\text { ZO } \\
\text { OT }\end{array}$ \\
\hline $\begin{array}{cl}\text { Dead Scleractinia } \\
\text { - } & \text { Dead Coral } \\
\text { - } & \text { Dead Coral (with } \\
& \text { Algae Covering) }\end{array}$ & $\begin{array}{c}\mathrm{DC} \\
\mathrm{DCA}\end{array}$ & \begin{tabular}{cl}
\multicolumn{2}{l}{ Abiotic } \\
- & Sand \\
- & Rubble \\
- & Silt \\
- & Water \\
- & Rock
\end{tabular} & $\begin{array}{c}\mathrm{S} \\
\mathrm{R} \\
\mathrm{SI} \\
\mathrm{WA} \\
\mathrm{RCK}\end{array}$ \\
\hline
\end{tabular}

Table 2.

Coral Coverage Condition Criteria Based on Living Coral Coverage Percentage

\begin{tabular}{|c|c|c|c|}
\hline Parameter & \multicolumn{3}{|c|}{$\begin{array}{l}\text { Standard Criteria of Coral Reef Damage } \\
\text { (in \%) }\end{array}$} \\
\hline \multirow{4}{*}{$\begin{array}{l}\text { Living Coral } \\
\text { Coverage } \\
\text { Width } \\
\text { Percentage }\end{array}$} & \multirow[t]{2}{*}{ Broken } & $\mathrm{Bad}$ & $0-24.9$ \\
\hline & & Fair & $25-49.9$ \\
\hline & \multirow[t]{2}{*}{ Fine } & Good & $50-74.9$ \\
\hline & & Very Good & $75-100$ \\
\hline
\end{tabular}

Evaluating a health or condition of coral reef ecosystem does not only based upon coral coverage percentage, because there may be two areas that have the same living coral coverage percentage, while their damage levels are different. This damage level is related to how vast the change from a living coral into a dead coral. Dead coral ratio may be found through coral mortality index with the following calculation (English et al., 1994) :

Mortality Index $=\frac{\text { Coverage Percentage (Dead Corals) }}{\text { Coverage Percentage (Deads + Living Corals }} \times 100 \%$

\section{Result and Discusion}

Electric Steam Power Plant (PLTU) Paiton is one of State Electricity Company (PLN) development project that has already built on April 1998. PLTU Paiton located on the beach outskirts of Binor Village Paiton District Probolinggo Regency East Java Province. There is a river or canal that is called Malikan canal around $6 \mathrm{~km}$ on the west side of this power plant. The effect of this river emerges on rainy season, especially on binor area, where it is directly in borderline to its outfall. Before founded, PLTU Paiton area was a mangrove spot with sand subtrate that is likely yield coral reef. The coral reed found on PLTU area is a new-born one. Observation and measurement are done in two kinds of depths, which are 3 meters and 10 meters depth.

Observation and measurement of coral reef are done around PLTU Paiton near the lighthouse. This location is formerly a coral transplantation area that is likely started 5-10 years ago, since there are remains of transplantation shelves buried underneath the complexity of branching coral structure. This transplantation shelves found from a shallow depth ( 2 meters) up to 10 meters depth.

\section{Coverage Percentage of Bentic Biotas in Paiton}

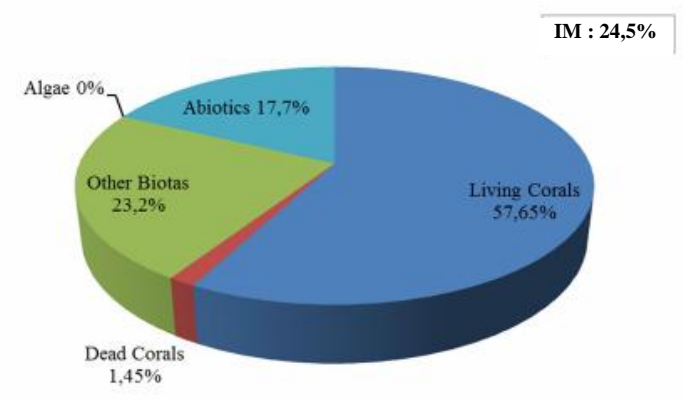

Figure 3. Benthic coverage percentage (\%) on Paiton Seashore observation site at 3 meters depth. IM represents coral mortality index $(\%)$.

Percentage of living coral coverage in 3 meters depth on this Binor Paiton seashore that may be categorized in a good condition is $57,65 \%$. While the rest are dead coral that is only $1,45 \%$, other life form in $23,2 \%$, and non-life form in $17,7 \%$. On the other hand, Mortality Index (IM) of coral reef resulted in $24,5 \%$ (Figure 3 ). A good condition of coral reef is caused by coral reef transplantation on the seashore, so this coral reef is dominated by Acropora Branching (Figure 4).

Coral reef observation and measurement results on that seashore are dominated by Hard Coral in Acropora Branching (ACB) with coral reef coverage percentage of $39 \%$, Coral Massif (CM) with coral reef coverage percentage of 2,85\%, Coral Foliose (CF) with coral reef 
coverage percentage of $1,6 \%$, and Coral Mushroom (CMR) with coral reef coverage percentage of $8,5 \%$ (Figure 5).

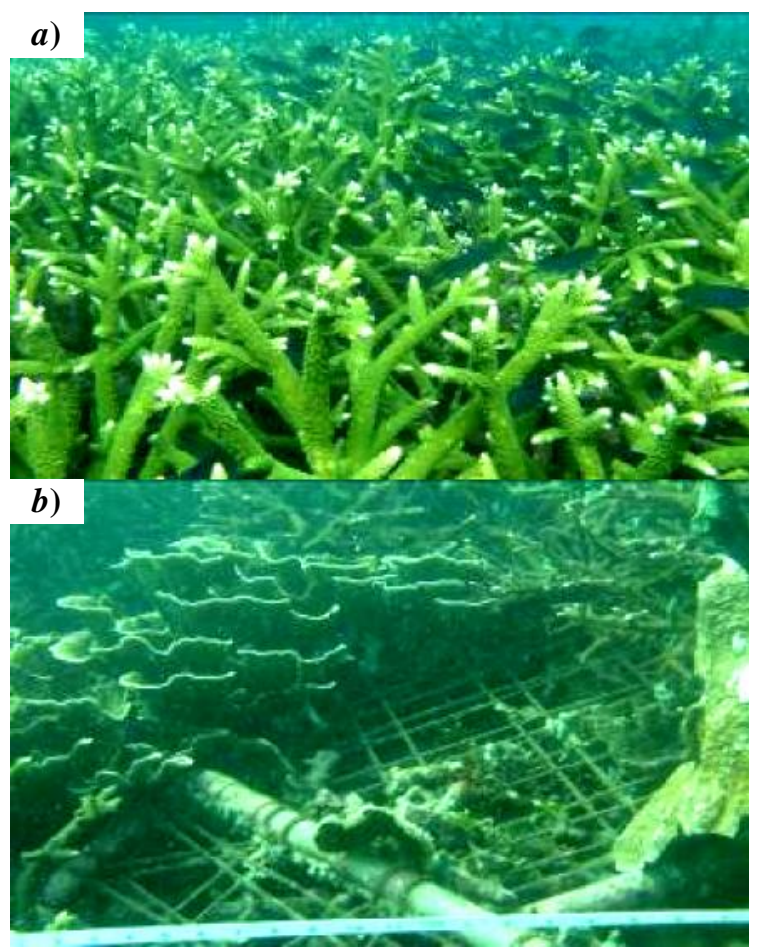

Figure 4. (a) Coral reef condition on Paiton at 3 meters depth, and (b) the remains of coral reef transplantation shelves.

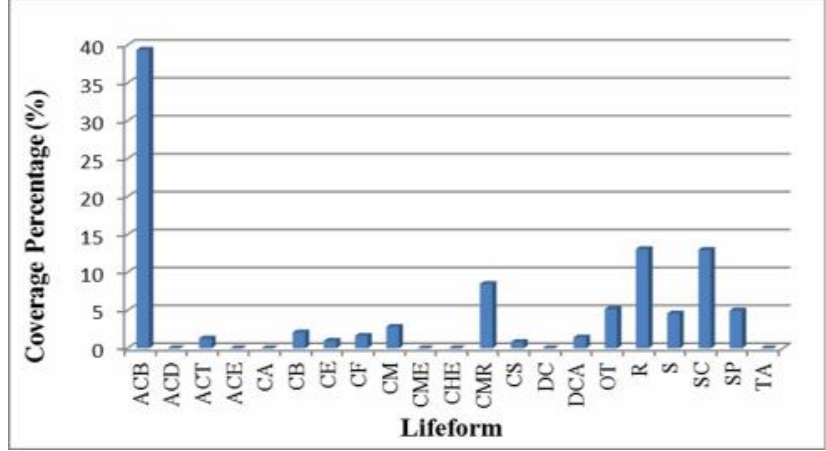

Figure 5. Benthic life form coverage percentage (\%) at 3 meters depth on Paiton Probolinggo Seashore.

Observation and measurement at 10 meters depth show that coral reef coverage is very wide, up to $63,33 \%$. Seventy five percent of living corals found at 10 meters depth are dominated by Acropora branched coral, and the rest $25,21 \%$ are filled by Acropora tabulate coral and non-Acropora coral with branched life form, massive, sub-massive, foliose, and mushroom, where coral Mortality Index (IM) reached 28,5\% (Figure 6). The high number of coral reef coverage percentage on Paiton is caused by successful coral transplantation and low activity of society in this location (Figure 7).

The domination of large size Acropora branching coral were estimated comes from a few types, showing that coral resulted from transplantation has grown large and form a complex 3 dimension structure that is suitable for the life form of fish and living benthic (Figure 8). But this domination also caused coral classification capital getting smaller. The success of coral transplantation program on this area is also supported by the small activity of fishery, so coral may grow well without any significant disruption.

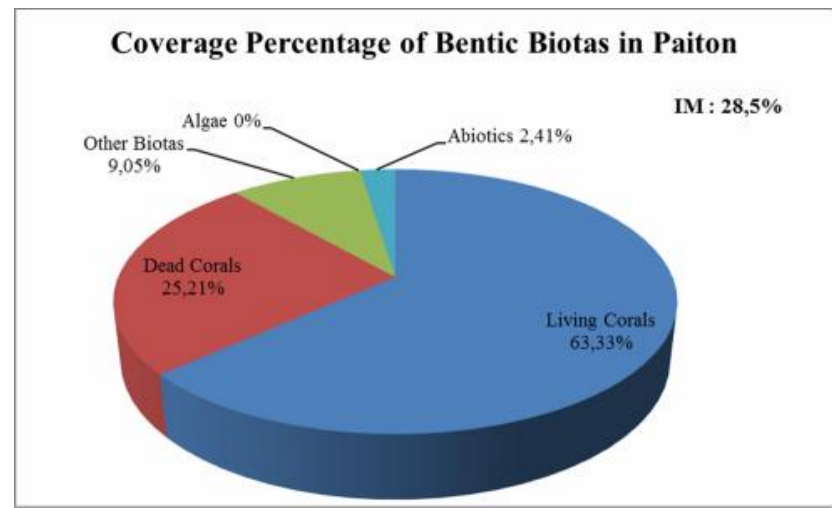

Figure 6. Benthic coverage percentage (\%) on Paiton Seashore observation site at 10 meters depth. IM represents coral mortality index $(\%)$.

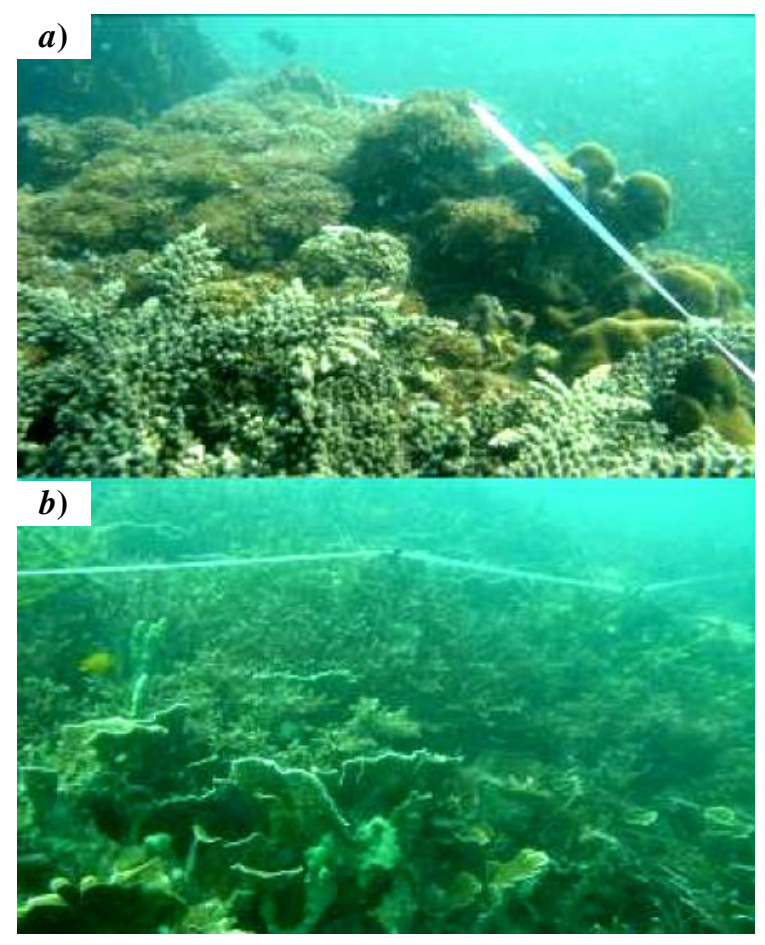

Figure 7. Subtrate condition on Paiton seashore at 10 meters depth that filled by hard coral. Domination occur on few coral species.

Aside from living coral, 25\% substrates at 10 meters depth are covered by dead coral (Figure 9). Dead coral found are mostly in branched or massive form, and the death is likely caused by competing position and shading. Acropora coral, especially in branched form, may grow well and fast vertically or horizontally. This caused smaller corals often giving up in competing space with the larger ones or getting less sunlight as it is closed by the coral network structure above. The large complexity of 3 dimensional substrate formed by branched coral caused only a few life form that may be observed along transect 
line (9\%). Though generally, variety of life form may be seen hiding below branched coral.

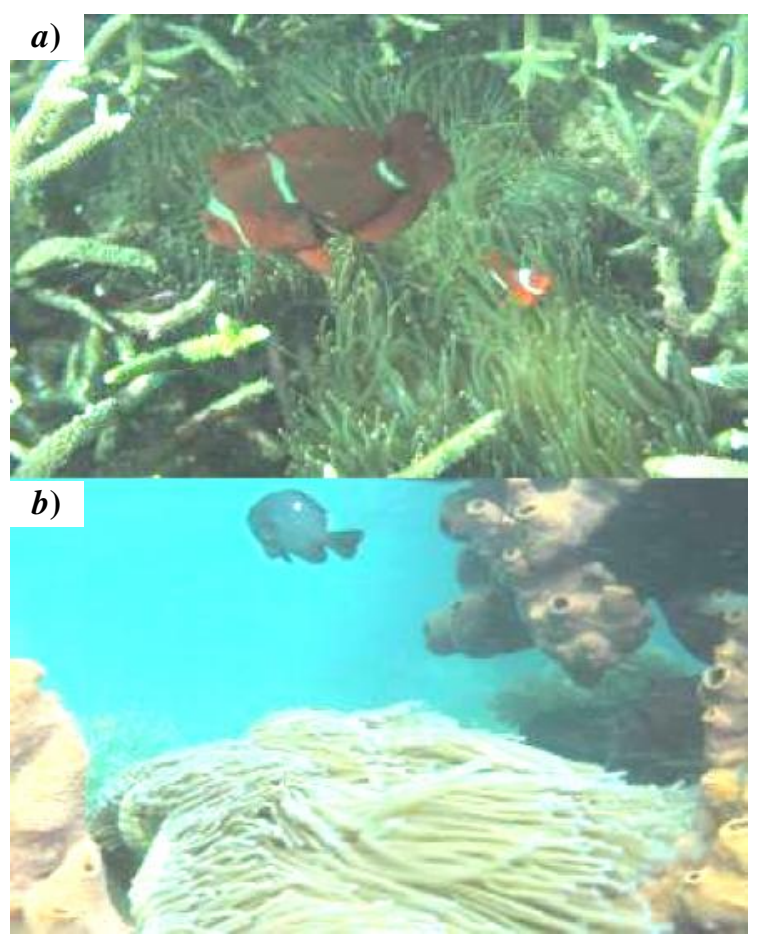

Figure 8. Few coral fish species found on Paiton Seashore

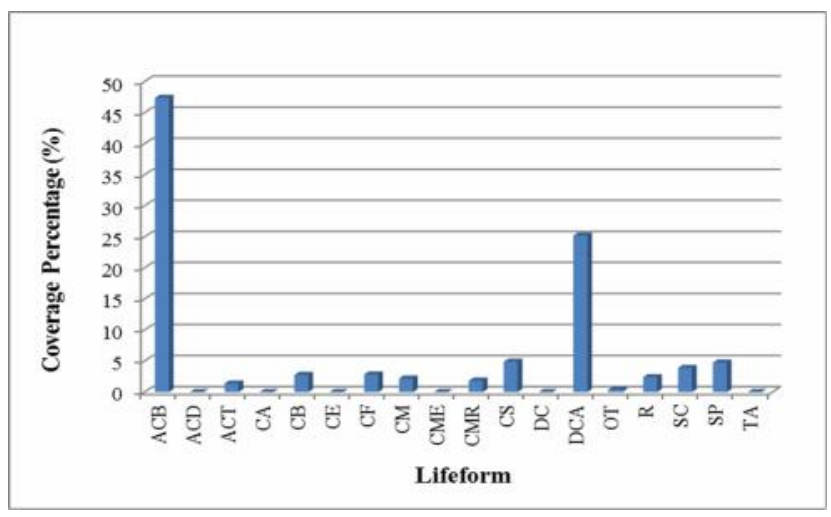

Figure 9. Benthic life form coverage percentage $(\%)$ at 10 meters depth on Paiton Seashore Probolinggo Regency.

\section{Conclusion and Suggestion}

\subsection{Conclusion}

1. Research site on Binor Paiton-Probolinggo seashore has the highest coral coverage percentage in $63 \%$. The high number of coral reef coverage percentage on Paiton is caused by successful coral transplantation and low activity of society in this location.

2. At 10 meters depth, $25 \%$ substrates are covered by dead coral. Dead coral found are mostly in branched or massive form, and the death is likely caused by competing position and shading.

\subsection{Suggestion}

Several coral reef rehabilitation activities have been conducted in East Java. Some of these activities have brought results, as it seen in Paiton. Hopefully, this rehabilitation activity does not short-lived, but becoming part of the long-run activity. Various additional researches are also needed to validate the effectiveness of this rehabilitation activity from ecology, social, and economy aspect for the long-term planning. With clear rules, several rehabilitation sites may be functioned as one of the diving or swimming place for tourists.

\section{Acknowledgments}

Author would like to thank for all those people who have provided assistance and facilities in the successful of this study.

\section{References}

Bengen, D. G. (2000). Sinopsis ekosistem dan sumberdaya alam pesisir. Bogor-Indonesia: Pusat Kajian Sumberdaya Pesisir dan Lautan, Institut Pertanian Bogor.

Buddemeier, R.W., Kinzie, R.A. III (1976) Coral growth. Oceanography and Marine Biology: An Annual Review, 14, 183-225.

Burke L, Selig E, Spalding M. 2002. Terumbu Karang Yang Terancam Di Asia Tenggara. Diterjemahkan dari Reefs at Risk in Southeast Asia. Washington, DC-USA: World Resource Institute.

Dahuri, R., Rais, J., Ginting, S. P., Sitepu, M. J. (1996). Pengelolaan Sumberdaya Wilayah Pesisir dan Lautan Secara Terpadu. Jakarta-Indonesia: PT. Pradnya Paramita.

Dahuri, R. (2003). Keanekaragaman hayati laut: aset pembangunan berkelanjutan Indonesia. Jakarta-Indonesia: Gramedia Pustaka Utama.

Dona, A. R., Cervino, J. M., Karachun, V., Lorence, E. A., Bartels, E., Hughen, K., Smith, G. W. \& Goreau, T. J. (2008, July). Coral Yellow Band Disease; current status in the Caribbean, and links to new Indo-Pacific outbreaks. In Proceeding of the 11th International Coral Reef Symposium, Ft. Lauderdale-Florida-USA, 7-11 July 2008 (pp. 239-243).

English, S., Wilkinson, C. C., \& Baker, V. V. (1994). Survey manual for tropical marine resources. Queensland-Australia: Australian Institute of Marine Science (AIMS).

Gomez, E. D., \& Yap, H. T. (1988). Monitoring reef condition. In: Kenchington, R. A. \& Hudson, B. E. T. (Eds.), Coral Reef Management Handbook. Jakarta-Indonesia: UNESCO Regional Office for Science and Technology for Southeast Asia (ROSTSEA).

Sjafrie, N. D. M. (2012). Kondisi Terumbu Karang dan Biota Lainnya di Perairan Kecamatan Selat Nasik Kabupaten Belitung Tahun 2007-2008. Jurnal Perikanan, 11(2), 150156.

(C) 2016 by the authors; licensee Udayana University, Indonesia. This article is an open access article distributed under the terms and conditions of the Creative Commons Attribution license (http://creativecommons.org/licenses/by/3.0/). 